\title{
American views of Sir Victor Horsley in the era of Cushing
}

\author{
Kurt R. Lehner, BS, and Michael Schulder, MD \\ Department of Neurosurgery, Hofstra Northwell School of Medicine, Manhasset, New York
}

Sir Victor Horsley was a pioneering British neurosurgeon known for his numerous neurosurgical, scientific, and sociopolitical contributions. Although word of these surgical and scientific achievements quickly spread throughout Europe and North America in the late 19th century, much of modern neurosurgery's view of Horsley has been colored by a single anecdote from John Fulton's biography of Harvey Cushing. In this account, Cushing observes a frenetic Horsley hastily removing a Gasserian ganglion from a patient in the kitchen of a British mansion. Not long after, Cushing left Britain saying that he had little to learn from British neurosurgery. The authors of this paper examined contemporary views of Horsley to assess what his actual reputation was in the US and Canada. The authors conducted a thorough search of references to Horsley using the following sources: American surgical and neurosurgical textbooks; major biographies; diary entries and letters; PubMed; newspaper articles; and surgical and neurosurgical texts. The positive reception of his work is corroborated by invitations for Horsley to speak in America. Research additionally revealed that Horsley had numerous personal and professional relationships with prominent Americans in medicine, including William Osler, John Wheelock Elliot, Ernest Sachs, and (yes) Harvey Cushing. Horsley's contributions to medicine and science were heavily reported in American newspapers; outside of neurosurgery, his strong opposition to the antivivisectionists and his support for alcohol prohibition were widely reported in popular media. Horsley's contributions to neurosurgery in America are undeniable. Writings from and about prominent Americans reveal that he was viewed favorably by those who had met him. Frequent publication of his views in the American media suggests that medical professionals and the public in the US valued his contributions on scientific as well as social issues. Horsley died too young, but not without the international recognition that was rightly his.

https://thejns.org/doi/abs/10.3171/2017.8.JNS171438

KEY WORDS Victor Horsley; history; legacy; Harvey Cushing

$\mathrm{M}$ UCH has been written about Sir Victor Horsley's (1857-1916) contributions to neurosurgery and science (Fig. 1). He took his first job as a surgeon at the National Hospital for the Paralysed and Epileptic in Queen Square, London, in 1886. He performed the first modern neurological surgery for epilepsy that same year. ${ }^{47,48}$ The next year, Horsley performed the first laminectomy for the removal of a spinal cord tumor, and he was the first surgeon to successfully operate on the cervical spine. ${ }^{47}$ In 1889 , he performed the first operation on the pituitary body, and he was the first to operate on craniopharyngiomas. ${ }^{38,39}$ The identification of the Foster Kennedy syndrome is also partially attributable to Horsley, who had also observed its localizing value with his young neurologist colleague. ${ }^{45}$ Horsley created a new composition of bone wax and popularized its use in surgery; the formula has remained largely unchanged to this day. ${ }^{37} \mathrm{He}$ developed the concept of stereotaxis (and coined the term) with his colleague Robert Clarke, with whom he designed their eponymous frame for his own animal experimenta- 


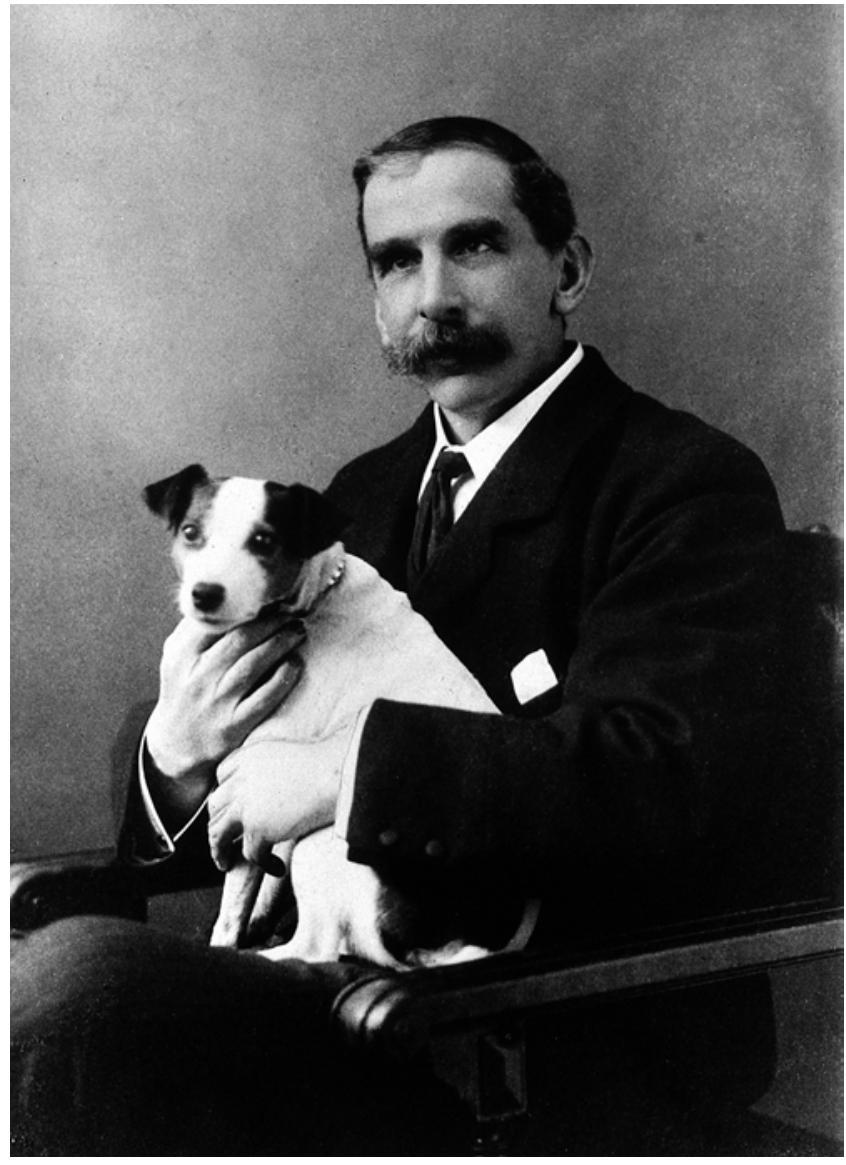

FIG. 1. Photograph of Sir Victor Horsley with his dog Noah. Image licensed under Creative Commons Attribution 4.0 International license CC BY 4.0 (https://creativecommons.org/licenses/by/4.0/), Wellcome Library no. 12928i.

tions on the cerebellum. Horsley's scientific contributions were equally impressive: he discovered that hypothyroidism was the cause of myxedema coma; as the result of his work with Louis Pasteur, rabies was eradicated from Great Britain by placing loose dogs in muzzle; he provided the first map of the homunculus in the motor strip of animals; and he made many other contributions to comparative anatomy. ${ }^{23,43}$ Horsley also was known for his controversial political views. He was a supporter of women's suffrage at a time when it was vastly unpopular, and he advocated for nationalized health care in Britain. Horsley was a vocal teetotaler and railed against the use of alcohol throughout his life. In short, he was a man who never failed to provide ideas and opinions and, in so doing, often provoked reactions from others.

In his well-known biography of Harvey Cushing (1869-1939), John Fulton describes Cushing's observation of Horsley operating on a patient who suffered from trigeminal neuralgia. Here, Cushing paints a picture of a frenetic, confused Horsley dictating letters to a secretary while entertaining his pet dogs over breakfast. Upon Cushing's mention of his operations on the Gasserian ganglion, Horsley offered to show Cushing his own technique for its removal. The following day, Horsley sterilized his instruments at home, packed them in a towel, and drove off with Cushing to the mansion where he operated. In a letter, Cushing stated: $:^{14}$

Horsley dashed upstairs, had his patient under ether in five minutes, and was operating fifteen minutes after he entered the house; made a great hole in the woman's skull, pushed up the temporal lobe-blood everywhere, gauze packed into the middle fossa, the ganglion cut, the wound closed, and was out of the house less than an hour after he had entered it.

Not long after this, Cushing decided to leave London; he felt that Horsley could do little to help refine the emerging field of neurosurgery, which would soon be defined by Cushing's adaptation of Halsted's aseptic and meticulous surgical method.

Views of Horsley, especially among American neurosurgeons, have largely been shaped by this passage. The Horsley biographer J. B. Lyons wrote in 2001, "It is likely that this passage, violent in style, and exaggerated in content, from a much publicized biography, harmed Horsley's reputation irremediably." ${ }^{2}$ The American neurosurgeon Paul Bucy (1904-1992) corroborated Fulton's writing, despite never seeing Mr. Horsley operate. He stated, "As Cushing had observed, Horsley was not a good technical surgeon."2 In our literature search, there was a remarkable paucity of material relating to Horsley following his death, with the exception of communication regarding a Horsley centenary lecture in 1957, giving credence to the view that Horsley was not widely discussed. Upon publication of The Citizen Surgeon: A Biography of Sir Victor Horsley, 1857-1916, Lyons received criticism from the American neurosurgeon Earl Walker, annoyed that he had called Horsley "the father of neurosurgery." 20,22 Lyons recognized "a modern trend in the historiography of neurosurgery...to denigrate Horsley." 22 Our research, however, finds that views of Horsley during his life are not in line with these views. On the contrary, contemporary American views of Horsley in neurosurgery, medicine, and the media were overwhelmingly positive.

\section{Literature Search}

The indices of the following texts were searched for "Horsley, Victor": The Principles and Practices of Medicine by W. Osler, 1892; Brain Surgery by M. Starr, 1893; Surgery, Its Principles and Practice, chapter on surgery of the head by H. W. Cushing, 1908; The Pituitary Body and Its Disorders by H. W. Cushing, 1910; and Surgery of the Spine and Spinal Cord by C. Frazier, 1920. The number of citations was recorded, and the relevant sections were read to assess the authors' views of Horsley.

Stephen Paget's biography Sir Victor Horsley: A Study of His Life and Work was examined for references concerning Horsley's travel to America. PubMed and Google Scholar searches for original texts from those events were conducted to ascertain Horsley's contributions and reception. Digital archives of newspapers from the locations of the events were searched for references to "Victor Horsley" at the time of his travels. The articles were collected and read to assess the American public's perception of Horsley.

Horsley's interactions with prominent American physi- 
cians and surgeons from the above texts were recorded, as well as from relevant biographies of those individuals, including Cushing's biography of Osler (The Life of Sir William Osler, Volumes 1 and 2), Fulton's biography of Cushing (Harvey Cushing: A Biography), and Bliss's biography of Cushing (Harvey Cushing: A Life in Surgery). Primary references cited in these sources were obtained from the Osler Library at McGill University and the Cushing Library at Yale University. Letters from Ernest Sachs (1879-1958) to Sir Geoffrey Jefferson (1886-1961) concerning the Victor Horsley Centenary Lecture in 1957 were obtained from the University of Manchester's collection of Sir Geoffrey Jefferson letters. A PubMed and Google Scholar search for articles authored by Ernest Sachs with the key word "Victor Horsley" were used to further characterize their relationship. A New England Journal of Medicine review of John Wheelock Elliot's life (1928) was also consulted.

Digital archives from the New York Times and American Library of Congress were searched for "Victor Horsley," and articles were counted and read to ascertain the American public's view of Horsley. JSTOR was also used for specific searches for information concerning Horsley's contributions to social and political issues of the time.

Information regarding Victor Horsley was supplemented with results obtained from a PubMed and Google Scholar search for "Victor Horsley" limited to the years 1870-1950. Primary articles published by Horsley and articles from non-American authors were excluded. Further information was gathered from reviews concerning Horsley's work published in peer-reviewed academic journals between 1986 and 2016.

\section{Horsley's Travels in America}

Paget's biography of Victor Horsley described 3 invitations to speak that resulted in 2 trips that Horsley made to America during his lifetime. Sir Victor Horsley first visited America on special invitation to speak at the 1888 Congress of American Surgeons and Physicians in Washington, DC. He participated in a discussion titled "On Cerebral Localization in Its Practical Relations," in which he referenced the findings of his experiments in neurophysiology and made a case for the existence of interconnected motor, tactile, and "muscular sense" centers in the cerebral cortex. ${ }^{37}$ The Evening Star, a Washington, DC, newspaper, reported a crowded and distinguished audience in attendance at the discussion and claimed that it was the "most brilliant of the series."'11

Horsley was next invited to speak at the Cartwright lectures at Columbia University in 1897, although he could not attend due to his busy surgical and scientific schedule. ${ }^{37}$ Horsley would not return to North America until 1906, where he spoke twice at the Canadian and British Medical Association meeting in Toronto. At the opening session of this meeting, a motion was made to make Sir Victor an honorary lifetime member of the Canadian Medical Association, after which the delegates "cheered for some moments [and] the motion was of course carried unanimously."50 A later article from the Toronto Star, commenting on Sir Victor's dress at the conference, says:49

Sir Victor Horsley, who understands a man's brain like a book, and scrapes it and pares it and digs out the bad parts so that it's as easy for one to be good after Sir Victor has done with him as it is for any of us to be honest after we get richwore a simple black gown with no frills. Such an absence of color in this brilliant assemblage made him a marked man, even if his reputation had not preceded him.

During this trip, he also gave a talk on temperance to an audience of 500 at the Ontario Branch of the Dominion Temperance Alliance and declared (not with complete accuracy) that "the medical profession of Great Britain as a whole was opposed to the use of alcohol as a drug and as a beverage...the value of alcohol as a drug was practically nil." ${ }^{46}$ Later, at a festival dinner for the British and Canadian Medical Associations, "a speech was loudly demanded from him." ${ }^{37}$ Stopping in New York on his return to London, the British pioneer's celebrity status garnered him mentions in the "Society" sections of newspapers in New York and Washington, DC. ${ }^{12,24}$ It is obvious from these anecdotes that Horsley was a sought-after speaker in America. His engagements drew large crowds and were well received and widely reviewed.

\section{Influence on American Neurosurgery}

The neurologist M. A. Starr (1854-1932) of Columbia University wrote Brain Surgery in 1893, making it one of the first compilations of experience with surgery on the CNS. Horsley's cases are referenced 15 times in the index, contributing to chapters on the diagnosis of cerebral disease, trephining for epilepsy, tumor, relief of intracranial pressure, headache, and the technique of trephining. The principles of cerebral localization, outlined by Horsley through his electrophysiological experiments, are referenced in localizing cerebral lesions. Horsley made use of the same faradic current on the cortex to identify intraoperatively what would now be referred to as "seizure onset zones" prior to resection in surgery for epilepsy. ${ }^{44}$

Characteristic of Horsley, his operations for epilepsy were not without controversy. Starr goes on to state that "excision of brain cortex is necessarily followed by the formation of a cicatrix which becomes the centre of a sclerotic patch in the brain... [which] may act as an irritant and give rise to localized epilepsy," citing 2 cases of Horsley's in which seizures recurred after resection. ${ }^{44}$ Sir William Osler (1849-1919) cited the same fears in an earlier work on indications for brain surgery. ${ }^{32}$ The final recommendation given by Starr is against the excision of a focus when there was no obviously abnormal brain present.

Brain Surgery also reveals that Horsley recommended operating on many tumors in the brain, including syphilitic gummata, especially when there were signs of increased intracranial pressure. Horsley recommended 6 weeks of medical treatment prior to surgery for gummata; on this point Starr explicitly disagrees, urging at least 3 months of treatment with no amelioration of symptoms prior to operation. Later, however, Starr details a case of "frontal lobe sarcoma" misdiagnosed as a syphilitic gumma. There was a delay in surgery in favor of medical treatment, which resulted in the patient's death due to hemorrhage in the perioperative period. The narrative ends with the concession: ${ }^{44}$

An earlier operation, when the tumor was much smaller and the vascularity of the tissues much less, would probably have 
been successful.... If Horsley's dictum had been accepted, namely, that gumma is not curable by medicine and should be operated for (a dictum, however, which the experience of others in several cases does not support), an earlier operation would perhaps have been undertaken.

As this passage demonstrates, in the late 19th century the indications for surgery on the CNS were being defined, and the text provides evidence of a scholarly discourse between the pioneers of brain surgery.

Cushing himself also referenced Horsley 21 times in his contribution to Keen's Surgery, Its Principles and Practice. In this seminal work, Surgery of the Head, comprising most of the third volume of Keen's 7-volume publication, Cushing outlines Horsley's contributions to palliative surgery for pain, surgery for syphilitic gummata, and surgery for epilepsy. Horsley's technique received positive comments: the use of a table extension for a headrest, constant irrigation of the brain with warm saline intraoperatively to prevent local cooling, use of bone wax for bone hemostasis, and the observation that there is rarely a need to remove normal brain tissue to access a deep growth, were all viewed as desirable innovations. Cushing supported Horsley's belief that early operations on confirmed intracranial growths improved outcomes. ${ }^{9}$

Horsley's subtemporal approach to pituitary tumors was described by Cushing as a "remarkable experience... not likely to be repeated by other than specialists in neurological surgery," a description not consistent with the description of Horsley's operation in Fulton's biography. Ernest Sachs, an early American student of Horsley's and a young colleague of Cushing, attributed the first operations on pituitary tumors to Horsley. In 1906, Sir Victor gave a lecture titled "On the Surgical Management of Pituitary Tumors" that provided evidence for this claim. ${ }^{37,39}$ Interestingly, however, mention of Horsley's pituitary surgery is scarce in Cushing's The Pituitary Body and Its Disorders, perhaps due to this text's endocrinological rather than surgical focus. Horsley is mentioned only twice, in reference to his experimental work on hypopituitarism and his subtemporal approach. Sir Victor never published his results of operating on pituitary tumors, likely contributing to this exclusion, although he is credited with possibly having had the largest individual surgical experience with this type of tumor at that time. ${ }^{8}$

Finally, Charles H. Frazier's seminal text Surgery of the Spine and Spinal Cord referenced Horsley 16 times in 3 different anecdotes. Horsley's first surgery on the spinal cord for spinal tumor in 1887 was described, and according to Frazier, spinal tumors were a "hopeless" condition at that time. Horsley removed an intradural extramedullary tumor at the level of the third and fourth thoracic vertebrae, after which the patient regained motor and sensory functions. The operation was referred to by multiple sources as "epoch-making" (see below regarding William Osler). The importance of the principles of spinal localization for the diagnosis of spinal pathology, outlined by Horsley's colleagues, like Charles Sherrington, is again discussed.13

Horsley's frequent citation in the surgical literature from the late 19th and early 20th centuries makes clear that he was a surgeon who had much to share with the world. In addition to his surgical outcomes and techniques, many texts cited his experimental work as well. Today, the frequency that one's work is cited is used as evidence of its value. If the same standard is used to measure Sir Victor's contributions, the fact that he was cited in the most prominent neurosurgical texts of the day speaks volumes about his influence.

\section{American Colleagues on Horsley \\ Sir William Osler}

Horsley and Sir William Osler first met in 1878 at University College London while he was still a student. ${ }^{4} \mathrm{Al}-$ though the meeting was brief, Osler followed Horsley's early scientific and surgical achievements closely, and they became close friends. Osler supported the doctrine of cerebral localization, and in 1881, he observed a discussion regarding the subject between the neurologists Ferrier, Brown-Sequard, and Jackson, with whom Horsley worked closely. Osler attended a lecture by Horsley on his experimental results in cerebral localization in $1884^{36}$ and visited Horsley's lab at the Brown Institution that same year. In 1885, Osler called Horsley's research on the origin of myxedema "a most important contribution to the physiology of the thyroid gland and its relation to the remarkable cretinoid condition." 7,35

Throughout his career, Osler was intensely interested in all aspects of neurosurgery, calling epilepsy surgery, in particular, "one of the most interesting aspects of modern surgery." ",, 32 In 1894, Osler attended a private operation for seizures considered to be "truly epileptic" where Horsley removed a meningioma the size of a fist and the seizures resolved. ${ }^{7}$ Horsley's pioneering removal of a spinal cord tumor was deemed "epoch-making" by Osler, further illustrating the respect Osler had for Horsley's surgical prowess, which he called "unequalled since John Hunter," arguably the founder of scientific surgery. ${ }^{34}$ In his contribution to Sir Victor's obituary, Osler called Horsley's mind "resolute, keen, and fertile... he had the true scientific spirit, open and free....and a fraternal kindliness that often gave to others the lion's share of credit." Osler's final published writing was a kindly review of Paget's biography of Sir Victor in which he called him "the outstanding British surgeon of his generation - the only one with the good fortune to create a new Department of Surgery." 33

\section{Elliot and Cushing}

John Wheelock Elliot (1852-1925), a pioneer in aseptic laparotomy in America and prominent surgeon at Massachusetts General Hospital (MGH), traveled to London in 1889, where he met a young Mr. Horsley just as the feasibility of brain surgery was becoming a reality. Inspired by the possibilities, Elliot returned to Boston and studied cerebral localization intensely, hoping to bring neurological surgery to Boston. In 1893, he had his first opportunity to operate on a brain tumor, and he performed a craniotomy for tumor removal (a cyst, in this case), the first successful brain surgery at MGH. Elliot did not continue to pursue neurological surgery, however (his interests were too diverse), but Horsley and he remained good friends and visited each other several times. While Elliot did not be- 
come a brain surgeon himself, he managed to spark interest in young doctors and students whom he trained. Most notably, Harvey Cushing, at the time a student at MGH, trained with Elliot in 1894 and $1895 .{ }^{6}$ It is perhaps during this period that Cushing found his calling, and it is not an exaggeration to say that Sir Victor Horsley was, albeit indirectly, crucial for the development of neurosurgery in America.

The Gasserian ganglion operation was the only operation of Horsley's that Cushing observed, but it appears that Cushing viewed Horsley as rather too brash a surgeon. In 1933, Cushing asked Ernest Sachs if he had ever seen Horsley turn down a bone flap as opposed to performing a craniectomy and continued, "I have an idea that he was too impetuous for this sort of fiddling, painstaking work which today we are so accustomed to do" (personal communication). In a letter to Sachs from the same year, Cushing emphasizes that Horsley was not particular about the bevel used in outlining a bone flap before he "broke out the bone in large pieces with an enormous pair of forceps about a yard long." He did, however, attribute Horsley's good outcomes-when prior outcomes had been so poorto his not replacing the flap, which allowed room for the brain to decompress. This implies that Cushing saw some of Horsley's techniques as reasonable, especially for the time, but ill-suited for the new modern era of neurosurgery.

Indeed, later writings from Cushing reveal that he had a great respect for Sir Victor. Following a trip to the British Medical Association meeting in London, he said that Horsley gave a "very interesting" talk on the thalamic region and also wrote, "Horsley is a daisy," implying that the interactions between the 2 men were cordial (Cushing diary entry, July 28, 1909). ${ }^{14}$ Cushing admired Horsley's views on animal experimentation and approved of his denouncements of antivivisectionists. ${ }^{14}$ Upon Horsley's death in Mesopotamia, Cushing described his contradictory feelings toward Horsley, highlighting the many qualities of his personality that could drive people away from him. However, he also writes, "What an unbelievable creature Horsley was-an absolute believer in himself and no other till the end...much that was amazing. His extraordinary energy...starting at five in the morning and dashing about till one's head reeled...Remarkable person" (Harvey Cushing, War Diary, January 1, 1918). In addition to Cushing softening his initially harsh views of Horsley, colleagues of Cushing also respected Horsley. Gilbert Horrax, Cushing's assistant, wrote, "It seems to me that there can be no possible dispute to the right of Sir Victor Horsley to be called the father of neurosurgery."16 In contrast to his portrayal of the initial meeting between Horsley and Cushing, Fulton described the later relationship between Cushing and Horsley as cordial and full of respect.

\section{Ernest Sachs}

Ernest Sachs traveled to England in 1907 to train in neurological surgery with Sir Victor Horsley. Like Cushing, Sachs had been trained in the Halsted school of slow and methodical surgery, and he admitted to experiencing shock when first seeing Horsley operate. He used antiseptic rather than aseptic technique and operated under constant antiseptic irrigation. His openings of the skull were crude and, as mentioned earlier, he never replaced the bone flap. As Sachs spent time with him, however, he observed that Horsley's "handling of the tissue was exquisite and very delicate," and his knowledge of anatomy and physiology was "superb" and "outstanding." 42

There were flashes of Horsley's argumentative personality. Sachs felt that Horsley was uncompromising when he believed that he was right, but was willing to change his mind when presented with incontrovertible evidence. ${ }^{43}$ Sachs also found Sir Victor to be extraordinarily generous. After completing his research conducted in Horsley's laboratory, Sachs presented a manuscript to Horsley with both men listed as authors. Horsley quickly crossed out his name, stating, "As long as it is customary, when two men publish a paper, to give credit to the one who is better known, I shall not allow my name to appear." 42

Other writings from Sachs also reveal that he thought highly of his mentor and that he considered Cushing's portrayal unfair. In a letter to the British neurosurgeon Geoffrey Jefferson regarding Horsley's politics (Ernest Sachs, letter to Geoffrey Jefferson, February 17, 1957), Sachs wrote, "He wasn't elected because he was too progressive. As you know, he and Lady Horsley were strong for Women's Suffrage." In the same letter, he also confessed:

Incidentally, as pure contributions to science, I am inclined to think Horsley's were more important than H.C.'s, naturally I wouldn't dare say that where J.F. [presumably referring to John Fulton] and Madeline Stanton [the initial librarian of the Yale Medical Historical Library and frequent collaborator with Fulton] are. I would lose the only place I can rest my head.

Sachs, reminiscing about his time with Sir Victor, wrote, "Of the many privileges that I have had in my life, working with various big men, that year and a quarter I spent with him I prize as the most valuable and delightful I ever had. I went to him in order to take up neurological surgery, and ever since my return to this country I have devoted myself to that work." 37

\section{Horsley in American Media}

A search of the New York Times digital database for "Victor Horsley" resulted in 9 articles. A search of the American Library of Congress's Chronicling America Historic American Newspaper archive revealed 124 results for "Victor Horsley." The Toronto Star archives had 12 results for "Victor Horsley." The contents of those articles are summarized below.

Neurosurgeons were not the only Americans aware of Horsley's work. He was recognized as a pioneer internationally, and the American media routinely reported his views on scientific and medical issues. As early as 1886 , Sir Victor's success in treating patients suffering from epilepsy was reported in newspapers throughout the country (Fig. 2). ${ }^{41}$ The New York Times published articles outlining Horsley's views on the evolution of the human brain and why people swing their arms when they walk. ${ }^{26,31}$ Dr. Charles Dana, a popular doctor writing for the New York Times, also reported on observing Horsley work; he said, "[Horsley] has been doing the most brilliant work 


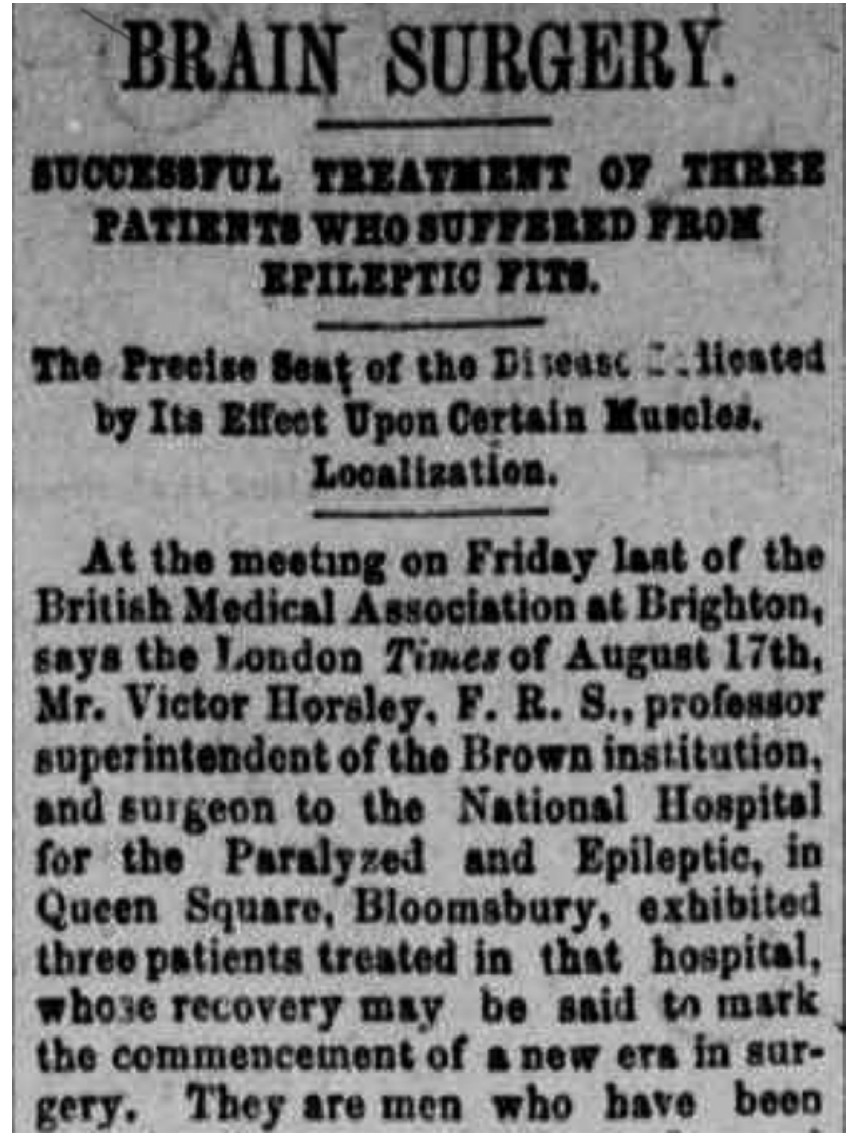

FIG. 2. A headline reporting Sir Victor Horsley's first successful operation for epilepsy in the Richmond Dispatch, September 12, 1886.

for years past, giving many hours daily to research, and now he is rewarded with splendid results." ${ }^{29}$ Horsley was always fascinated by the effects of bullet wounds to the head and how they led to death, and "the great London surgeon's" findings on this subject were disseminated by telegram to local newspapers throughout the US. ${ }^{18,51}$

Horsley's views on social issues were also reported widely. His support of animal experimentation was well known, and his name even appeared twice in New York Times headlines on the subject (Fig. 3). ${ }^{27,30}$ In "The Vivisector's Battle," a compelling interview with Horsley in his lab is reported. As "the most prominent figure" supporting animal research, Horsley said that he was "delighted...to afford the public any opportunity to judge for themselves the cruelty of our methods." The description of the lab is graphic: hemispherectomies were being conducted on cats and monkeys that had had spinal cords removed. The reporter, however, does not appear disturbed by this, and these images are overshadowed by Horsley's overwhelming care for his patients and the animals. He is careful to ensure that the animals do not suffer at any point in the experiment, and he speaks of the progress that can be made in surgery through better understanding of physiology.

Likewise, Horsley's stance against alcohol was widely known, even advertised, throughout the US (Fig. 4). At the time (as it is still), the medicinal value of alcohol was widely debated, and newspapers across the US wrote about

\section{THE VIVISECTOR'S BATTLE \\ PROF. HORSLEY'S LABORATORY FOR STUDYING THE LIVE BEAST. \\ CATS AND MONKEYS JOLLY WITH HALF \\ A BRAIN APIECE-ABSOLUTE PAIN- LESSNESS OF EXPERIMENTS-GREAT GAINS TO HUMANITY FROM THE STUDY-FALSEHOODS REPEATED BY MISS COBBE AND THE BISHOPS-A TEN YEARS CAMPAIGN OF VITU- PERATION AGAINST MEN OF BCIENCE.
BY THE COMMERCLAN CABLE FROM OUR OWN CORRESPONDENT. \\ Copyrighted. 1892, by the New. York Times.}

FIG. 3. An 1892 headline from the New York Times profiling Victor Horsley's experiments and conflict with the antivivisectionists.

Horsley's opposition to its use. ${ }^{46}$ The Putnam County Herald in Cookeville, Tennessee, is one of many local papers that reported on Horsley's condemnation of providing alcohol at public and private banquets and dinner parties. ${ }^{5}$ Sir Victor was vocal in his opposition to the rum ration in the British army, and the New York Times published Horsley's list "so long and dreadful as to be almost funny" outlining the effects of moderate rum (and other alcohol) indulgence: 19,28

Decadence of morale; causation of friction and disorder;

drunkenness; punishment; degradations in rank; decadence of observation and judgment; causation of errors and accidents; loss of endurance and diminution of physical vigor; causation of fatigue, falling out, and slackness; loss of resistance to cold; causation of chilliness, misery, and frostbite; loss of resistance to disease, particularly that occurring under conditions of wet and cold, namely, pneumonia, dysentery and typhoid fever;

loss of efficiency in shooting. Half the rum ration causes a

loss of 40 to 50 per cent in rifle shooting.

Horsley is frequently mentioned in American newspapers in the early 20th century, sometimes with no need to explain who he was or sometimes by simply calling him "the famous surgeon." Even his views on the origin of World War I were reported..$^{25}$ Newspapers throughout the US covered his death sympathetically, speaking highly of his contributions to science, surgery, and society. It appears that Horsley was something of an international celebrity in his time.

\section{Discussion}

Did Fulton's description of Sir Victor fit other descriptions of Horsley's personality? A classmate described him as keen and energetic, with "a strong hatred of humbug of all kinds: he protested against words and phrases like 


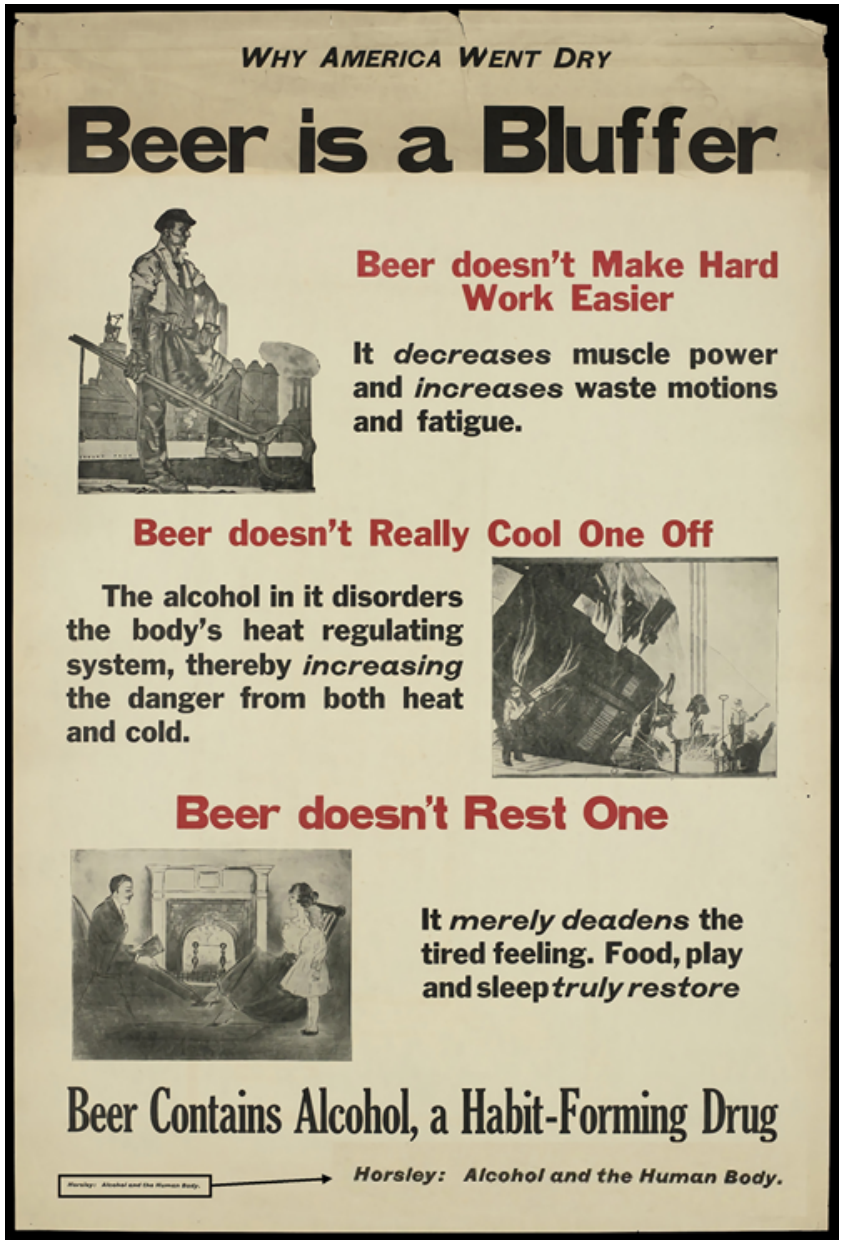

FIG. 4. An American advertisement from the Scientific Temperance Federation in Boston, Massachusetts, concerning the effects of alcohol on the human body citing Horsley's Alcohol and the Human Body on the bottom left. Image licensed under Creative Commons Attribution 4.0 International license CC BY 4.0 (https://creativecommons.org/licenses/ by/4.0/), Wellcome Library no. 679992i. Figure is available in color online only.

'special idiosyncrasy,' which he called a mere cloak for ignorance. He also held strong views on subjects like food, alcohol, etc. Mustard and suchlike condiments he denounced with vigour." The same classmate goes on to say he "must have had controversies with persons...I think everyone admired him, so thoroughly sincere, genuine, as he was, brilliant in intellect and blameless in life." ${ }^{37}$ Horsley could certainly have been perceived as quarrelsome and arrogant, overly talkative, and a touch too ambitious. But the prevailing later view of Horsley as a lesser surgeon, as outlined by Fulton, is not supported by the evidence.

Interestingly, Cushing's diary from the day described in Fulton's biography only briefly mentions Horsley interrupting breakfast to dictate a letter to his secretary. It was then followed by a dry description of the fateful operation, which we also learn was complicated by damage to the lateral sinus that was ligated; there was no mention of massive hemorrhage (Cushing diary entry, July 4, 1900). In a later diary entry from that same trip, Cushing described an operation for gallstones by another surgeon as making him "shudder." After 2 hours, a stone was found in

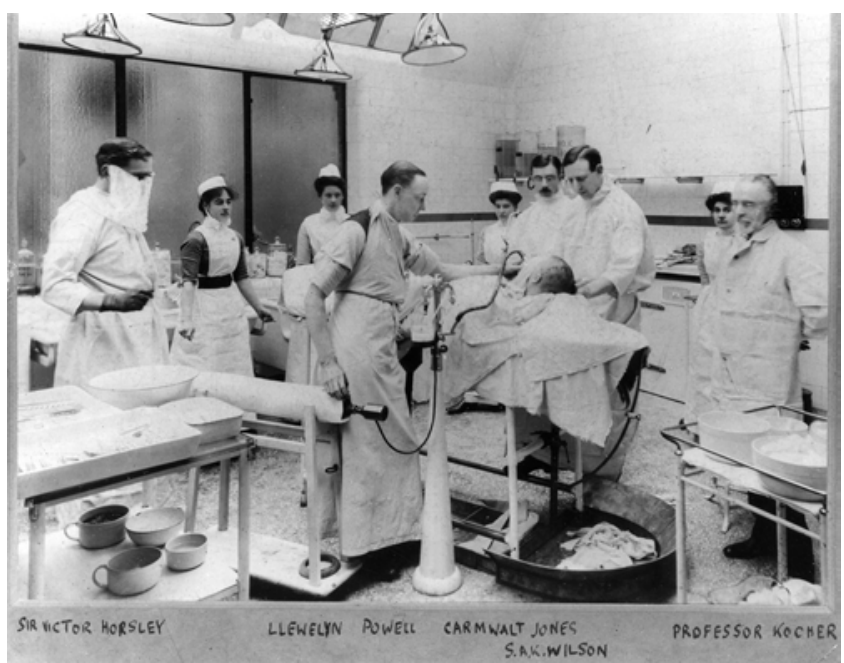

FIG. 5. Photograph of Sir Victor Horsley, at the far left, taken for his address in Toronto. His bulk is from a large antiseptic dressing placed to sterilize the skin prior to an appendectomy he was to undergo the next morning. Image courtesy of the Queen Square Archives, University College London.

the common bile duct that was "approached through the duodenum" (emphasis Cushing, diary entry July 17, 1900). Seeing this operation surely contributed to Cushing's idea that he had little to learn from his time in London, and Cushing's many descriptions of operations in which he greatly disagreed with British technique suggest an overall distasteful view of London surgery in general rather than of Horsley's operation in particular. It is also doubtful that Horsley's general practices deviated greatly from the standard of care in London at the time. He was trained in Lister's antiseptic technique rather than Halsted's refined aseptic method. Antisepsis valued speed, as prolonged exposure of the patient to the environment increased the risk of infection. There were no radiographs in Horsley's early years, and he helped develop the art of neurological localization.

Cushing, on the other hand, trained under Halsted (Fig. 5). The refinement of anesthesia and the aseptic technique allowed Cushing's mentor to develop a slow, meticulous surgical technique with remarkable outcomes. ${ }^{3}$ Cushing championed the same approach: he was slow and methodical, sometimes described as "dull." The operating room was silent. He would fastidiously track blood pressure throughout the surgery and developed methods and devices to obtain careful hemostasis at all times, all part of what was known as the "Cushing ritual." 14,15 In his monograph for Keen's surgical text, he wrote, "There should be a legal penalty imposed for 'speeding' in brain surgery."'

While Cushing was a picture of self-control, conservative and self-confident in character, Horsley was vocal in his opinions but quite modest with a distaste for "brash self-confident Americans." Cushing, when possible, replaced the bone flap in the skull after surgery; Horsley told Cushing "never to think of putting back a bone flap" (personal communication). Cushing smoked cigarettes heavily; Horsley detested cigarettes. ${ }^{40}$ Cushing's research was primarily clinical with little time for basic science that could not be immediately used. Horsley, on the other hand, was 


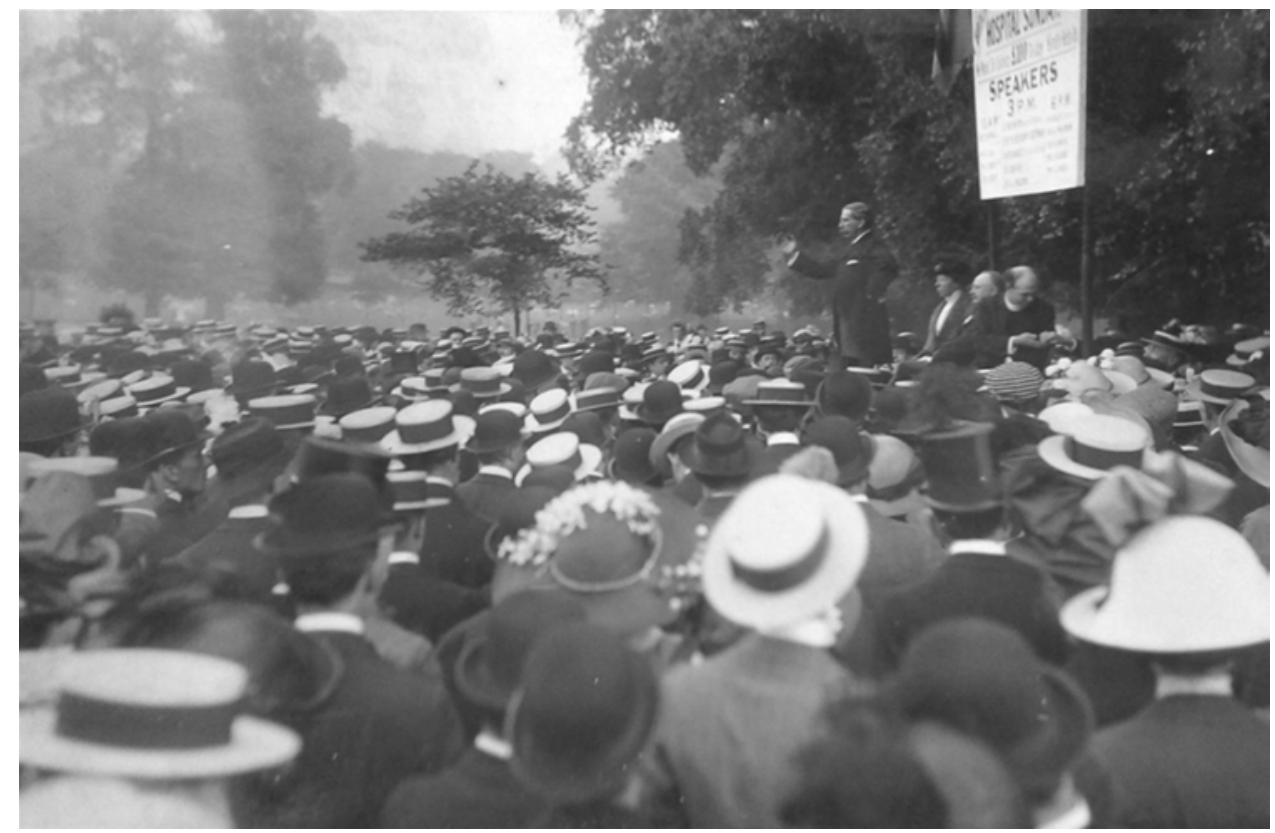

FIG. 6. Photograph of Sir Victor Horsley speaking to a large crowd. Image courtesy of the Queen Square Archives, University College London.

fascinated by all aspects of basic science; upon the death of a walrus at the London Zoo, Horsley rushed "to the Gardens, he dashed over to the appointed place and-though there was snow on the ground-in his shirt-sleeves took out the brain of the walrus, and returned to attend to his daily routine." ${ }^{37}$ When called upon for consults during this frenzy, he replied, "If people want me to learn they must be willing to wait." ${ }^{42}$ It is hard to picture 2 people more different in character than Cushing and Horsley, and these men could have easily misunderstood one another upon first meeting.

Cushing pushed for focusing on the "special field" of neurosurgery alone. Horsley, on the other hand, had interests in diverse fields, from basic biology to politics. Horsley was an expert in comparative anatomy: he had dissected and studied the brains of monkeys, dromedaries, and elephants (in addition to the abovementioned walrus). ${ }^{42,43,47}$ $\mathrm{He}$ was a lifelong teetotaler and outspoken advocate of prohibition. ${ }^{17}$ His politics were left leaning: he advocated for women's voting rights and was repeatedly told that he did not take a hard-enough stance against the suffragettes' violence (Fig. 6). In fact, some would argue that this is why he was never elected to Parliament despite his frequent campaigning later in his life. ${ }^{37}$ Sir Victor was also a candid proponent of Britain's National Insurance Act of 1911, a major step toward the eventual creation of Britain's National Health Service. In lobbying for the bill, he was decried by members of the British Medical Association as a "socialist," and exchanges between Horsley and other Association members led to Horsley eventually severing ties with the group. ${ }^{10}$

Sir William Osler also lamented Horsley's forays into politics: "What demon drove a man of this type into the muddy pool of politics?" At the same time, however, he saw them as inevitable: the aspects of his personality that drove his success in surgery and science drove him into politics. "A born reformer, he could not resist. Fearless, dogmatic, and assertive... a hard hitter, and always with a fanatical conviction of the justice of his cause, what wonder that the world's coarse thumb and finger could not always plumb the sincerity of his motives!" ${ }^{44}$ Cushing was more dismissive of this aspect of Horsley, mentioning his "political campaigns and demagogic talk to the lower classes-how long would they endure the oppression of the autocrats" on the day he learned of Horsley's death (Harvey Cushing, War Diary, January 1, 1918). With Horsley's increasing political activity in later life-spending less time in the operating room and the laboratory-it is not hard to imagine that this changed his reputation in America and partially overshadowed his scientific and surgical achievements.

On first impression, it is not hard to imagine that Horsley rubbed a young, ambitious Cushing the wrong way. The profound influence Cushing had on the development of American neurosurgery subsequently colored Horsley's reputation among neurosurgeons in America. Combined with his left-leaning political views, which likely would have been considered unacceptable by many in America, his reputation was diminished further. Lyons wrote, "[Horsley] had an instinct for friendship, but lost many of his friends through a penchant for controversy which amounted to a vice." ${ }^{21}$ C. J. Bond (1856-1939), a British surgeon and close friend of Horsley's, wrote:

If I were asked what causes appealed most strongly to Horsley's generous nature I should reply, the Search for Knowledge, the Dispersal of Ignorance, and the Righting of Wrong in every sphere of life. His ardent wish to relieve suffering in every form, and his sympathy with the sufferer were deeprooted instincts in his nature and greatly influenced his surgical work and outlook. ${ }^{1}$

This "penchant for controversy" perhaps came to over- 
shadow the rest of Horsley's accomplishments in Cushing's time, but this is surely an inaccurate characterization of Horsley's personality and motivations.

Horsley's life was tragically cut short while serving as a supervising surgeon, a position for which he had volunteered, in the British Army in Mesopotamia during World War I. Steadfast in his belief that a teetotaler like himself was immune to the effects of heat, Sir Victor took off walking across the Mesopotamian desert to see a patient on a humid day with temperatures over $110^{\circ} \mathrm{F}$. He fell ill, although he may have already been suffering from an infection at that time. Within 2 days, he developed a temperature of $107^{\circ} \mathrm{F}$, lapsed into a coma, and died on July 16,1916 , at 60 years old. In a letter to his wife only a few months prior Horsley had written, “Don't worry about me, I don't matter, I can't live forever, it's the young that matter." 37

\section{Conclusions}

Although the legacy of Victor Horsley in America may have been muddied by Cushing and Fulton's anecdote and Horsley's strong personality, current neurosurgery has acknowledged the profound influence Sir Victor had on the development of the "special" field. Writings from and about prominent Americans during Horsley's time reveal that he was thought of highly by American physicians and surgeons. The dissemination of his views in American newspapers also reveals that his opinions were valued by the public and that they were very aware of the great British pioneer. Any notion that Horsley's reputation suffered by comparison with Cushing is misplaced. The legacy of Sir Victor Horsley includes the high esteem in which he was held in North America, by colleagues and many others.

\section{Acknowledgments}

The authors wish to thank Dr. Edward Laws and Mr. Michael Powell for their advice, encouragement, and the inspiration for this article.

\section{References}

1. Bond CJ: Recollections of Student Life and Later Days. London: HK Lewis, 1939

2. Bucy PC: Neurosurgical Giants-Feet of Clay and Iron. New York: Elsevier, 1985

3. Cameron JL: William Stewart Halsted. Our surgical heritage. Ann Surg 225:445-458, 1997

4. Canale DJ: William Osler and "the special field of neurological surgery". J Neurosurg 70:759-766, 1989

5. Citizen: Alcohol and doctors. Citizen. June 23, 1904, 2 (col. 5)

6. Codman EA: John Wheelock Elliot, MD. N Engl J Med 198:994-1004, 1928

7. Cushing H: The Life of Sir William Osler. London: Oxford University Press, 1925

8. Cushing H: The Pituitary Body and Its Disorders: Clinical States Produced by Disorders of the Hypophysis Cerebri. Philadelphia: J.B. Lippincott, 1910

9. Cushing H: Surgery. Its Principles and Practice. Philadelphia: W.B. Saunders, 1908

10. Dunnill MS: Victor Horsley (1857-1915) and National Insurance. J Med Biogr 21:249-254, 2013

11. Evening Star: Cerebral localization. Evening Star. September 20, 1888, 5 (col. 3)

12. Evening Star: World of society. Evening Star. August 30, 1906, 5 (col. 5)
13. Frazier CH: Surgery of the Spine and Spinal Cord. New York: D. Appleton, 1918

14. Fulton JF: Harvey Cushing: A Biography. Springfield, IL: Charles C Thomas, 1946

15. Gavrus D: Skill, judgement and conduct for the first generation of neurosurgeons, 1900-1930. Med Hist 59:361-378, 2015

16. Horrax G: Neurosurgery. An Historical Sketch. Springfield, IL: Charles C. Thomas, 1952

17. Horsley V, Sturge MD: Alcohol and the Human Body: An Introduction to the Study of the Subject, and a Contribution to National Health. London: Macmillan, 1909

18. Indianapolis Journal: Artificial respiration. It should be employed when the head is wounded by gunshot. Indianapolis Journal. January 10, 1897, 3 (col. 5)

19. Liberal Democrat: Rum in the British Army. Liberal Democrat. May 7, 1915, 5 (col. 5)

20. Lyons JB: The Citizen Surgeon. A Biography of Sir Victor Horsley, 1857-1916. London: Dawnay, 1966

21. Lyons JB: Sir Victor Horsley. Med Hist 11:361-373, 1967

22. Lyons JB: Sir Victor Horsley (1857-1916) revisited, in Rose FC (ed): Twentieth Century Neurology: The British Contribution. London: Imperial College Press, 2001

23. MacNalty A: Sir Victor Horsley: his life and work. Br Med J 1(5024):910-916, 1957

24. New York Daily Tribune: About people and social incidents. New York Daily Tribune. August 30, 1906, 6 (col. 5)

25. New York Times: Blames secret diplomacy: One of the two chief causes of the war, says Sir Victor Horsley. New York Times. January 1, 1915, 3 (col. 8)

26. New York Times: The relative size of brains. New York Times. August 4, 1907, 6 (col. 2)

27. New York Times: Sir Victor Horsley defends vivisection. New York Times. September 20, 1908, Sect C; 3 (col. 7)

28. New York Times: Threatening more prohibition. New York Times. March 2, 1915, 8 (col. 4)

29. New York Times: Treats brain with needle. New York Times. September 3, 1911, Sect C; 3 (col. 5)

30. New York Times: The vivisector's battle-Prof. Horsley's laboratory for studying the live beast. New York Times. October 30, 1892, 1 (col. 3)

31. New York Times: Why we swing our arms. New York Times. June 27, 1909, Sect C; 1 (col. 1)

32. Osler W: On the conditions of the brain suitable for operative interference. Can Practitioner 14:165-167, 1889

33. Osler W: Sir Victor Horsley, a study of his life and work. Review. Oxford Magazine 38:175, 1920

34. Osler W: Sir Victor Horsley. Obituary. Br Med J 2:165, 1916

35. Osler W: The thyroid gland and myxedema. Med Newsl (Lond) 46:381, 1885

36. Osler W: The VII International Medical Congress, London August 10, 1881. Can Med Surg J 10:121-125, 1881

37. Paget S: Sir Victor Horsley: A Study of His Life and Work. New York: Harcourt, Brace and Howe, 1920

38. Pascual JM, Prieto R, Mazzarello P: Sir Victor Horsley: pioneer craniopharyngioma surgeon. J Neurosurg 123:39-51, 2015

39. Pollock JR, Akinwunmi J, Scaravilli F, Powell MP: Transcranial surgery for pituitary tumors performed by Sir Victor Horsley. Neurosurgery 52:914-926, 2003

40. Powell MP: Sir Victor Horsley at the birth of neurosurgery. Brain 139:631-634, 2016

41. Richmond Dispatch: Brain surgery. Successful treatment of three patients who suffered from epileptic fits. Richmond Dispatch. September 12, 1886, 7 (col. 3)

42. Sachs E: Reminiscences of an American student. Br Med J:916-917

43. Sachs E: Victor Horsley. J Neurosurg 15:240-244, 1958

44. Starr M: Brain Surgery. New York: William Wood \& Company, 1893 
45. Stone JL, Vilensky J, McCauley TS: Neurosurgery 100 years ago: the Queen Square letters of Foster Kennedy. Neurosurgery 57:797-808, 2005

46. Sun: Value of alcohol as a drug. Sun. September 9, 1906, 6 (col. 7)

47. Tan TC, Black PM: Sir Victor Horsley (1857-1916): pioneer of neurological surgery. Neurosurgery 50:607-612, 2002

48. Taylor DC: One hundred years of epilepsy surgery: Sir Victor Horsley's contribution. J Neurol Neurosurg Psychiatry 49:485-488, 1986

49. Toronto Daily Star: The doctors' daily rounds. Toronto Daily Star. August 22, 1906, 1 (col. 7-8)

50. Toronto Daily Star: Doctors welcomed to Toronto by the mayor. Toronto Daily Star. August 21, 1906, 1 (col. 5-6)

51. Washington Herald: Defends flat-nosed bullet. Washington Herald. January 3, 1915 (col. 6)

\section{Disclosures}

The authors report no conflict of interest concerning the materi- als or methods used in this study or the findings specified in this paper.

\section{Author Contributions}

Conception and design: Schulder. Acquisition of data: both authors. Analysis and interpretation of data: both authors. Drafting the article: Lehner. Critically revising the article: both authors. Reviewed submitted version of manuscript: both authors. Approved the final version of the manuscript on behalf of both authors: Schulder. Administrative/technical/material support: Lehner.

\section{Supplemental Information}

Previous Presentations

Portions of this work were presented at the Congress of the Spanish Neurosurgery Society in Barcelona, Spain, in May 2017.

\section{Correspondence}

Michael Schulder: Hofstra Northwell School of Medicine, North Shore University Hospital, Manhasset, NY. mschulder@ northwell.edu. 